\title{
PENGARUH ASUPAN PURIN DAN CAIRAN TERHADAP KADAR ASAM URAT WANITA USIA 50-60 TAHUN DI KECAMATAN GAJAH MUNGKUR, SEMARANG
}

\author{
Ervi Diantari, Aryu Candra*) \\ Program Studi Ilmu Gizi Fakultas Kedokteran Universitas Diponegoro \\ Jl.Dr.Sutomo No.14, Semarang, Telp (024) 8453708, Email : gizifk@undip.ac.id
}

\begin{abstract}
Background : Gout is one of the degenerative disease that often suffered by pre elderly women. Gout is a metabolic disorder characterized by increased levels of uric acid (hyperuricemia). Increased uric acid levels are influenced by dietary intake of high-purine. Meanwhile, high fluid intake could reduce the uric acid levels, because fluid serves as a solvent and disposal media of the body's metabolism.

Methods : this research was observational study with cross-sectional design. Subject were 40 women aged 50-60 years. Purine intake was calculated using tables of food groupings according to levels of purines, and fluid intake was calculated by nutrisurvey software. The levels of uric acid in the blood was measured with enzymatic methods. Data was processed using the linear regression.

Results : Most of subjects (95\%) had uric acid levels in the normal category. Total of $82.5 \%$ subjects purine intake was low, less than $500 \mathrm{mg}$ per day and $85 \%$ of fluid intake subjects was adequate, more than $\geq 1500 \mathrm{ml}$ per day. Statistical test results showed no effect between fluid intake and uric acid levels, meanwhile there were a positive effect of purine intake on uric acid levels.

Conclusions : Intake of purine affect the levels of uric acid, while the fluid intake had no effect on uric acid levels in women aged 50-60 years.
\end{abstract}

Keyword : purine; liquid; pralansia; gout

\section{ABSTRAK}

Latar Belakang : Salah satu penyakit degeneratif yang sering dialami oleh golongan pralansia yaitu penyakit gout. Gout merupakan gangguan metabolik yang ditandai dengan meningkatnya kadar asam urat (hiperurisemia). Meningkatnya kadar asam urat dipengaruhi oleh asupan makanan tinggi purin. Sementara, konsumsi cairan yang tinggi dapat menurunkan kadar asam urat, karena cairan berfungsi sebagai pelarut dan sebagai media pembuangan hasil metabolisme.

Tujuan : Penelitian ini bertujuan mengetahui pengaruh asupan purin dan cairan terhadap kadar asam urat wanita usia 50-60 tahun.

Metode : Jenis penelitian adalah observasional dengan rancangan cross-sectional. Jumlah subjek penelitian adalah 40 orang wanita usia 50-60 tahun. Asupan purin dihitung menggunakan tabel pengelompokan bahan makanan menurut kadar purin, sedangkan cairan menggunakan software nutrisurvey. Metode enzimatik digunakan untuk menganalisis kadar asam urat dalam darah. Data diolah menggunakan uji regresi linier.

Hasil : Kadar asam urat sebagian besar subjek (95\%) termasuk dalam kategori normal. Sebanyak 82,5\% asupan purin subjek rendah, yaitu $<500 \mathrm{mg}$ per hari dan juga 85\% asupan cairan subjek cukup, yaitu >1500 ml per hari. Hasil uji statistik menunjukkan tidak ada pengaruh antara cairan dengan kadar asam urat $(p>0,05)$ dan ada pengaruh positif asupan purin terhadap kadar asam urat $(p<0,05)$.

Kesimpulan : Asupan purin berpengaruh terhadap kadar asam urat, sedangkan cairan tidak berpengaruh terhadap kadar asam urat pada wanita usia 50-60 tahun.

Kata kunci : purin; cairan; pralansia; gout

\section{PENDAHULUAN}

Meningkatnya angka harapan hidup di Indonesia terjadi karena peningkatan taraf hidup dan pelayanan kesehatan, yang mengakibatkan populasi lansia di Indonesia semakin tinggi. Populasi lansia di Indonesia tahun 2009 jumlahnya meningkat menjadi 25,5 juta jiwa dengan usia harapan hidup 67,5 tahun. ${ }^{1}$ Secara individu, pengaruh proses penuaan menimbulkan berbagai masalah baik secara fisik, biologis, mental maupun sosial ekonominya. Angka kesakitan pada penyakit tidak menular seperti kanker, penyakit kardiovaskuler dan penyakit degeneratif lainnya memperlihatkan kecenderungan yang semakin meningkat. Salah satu penyakit yang sering dialami oleh golongan pralansia yaitu penyakit gout. Gout merupakan gangguan metabolik yang 
ditandai dengan meningkatnya kadar asam urat (hiperurisemia). ${ }^{2}$

Asam urat merupakan hasil metabolisme akhir dari purin yaitu salah satu komponen asam nukleat yang terdapat dalam inti sel tubuh. Meningkatnya kadar asam urat dalam darah disebut hiperurisemia. Hiperurisemia disebabkan oleh dua hal, yaitu karena pembentukan asam urat yang berlebihan atau karena penurunan pengeluaran asam urat oleh ginjal. Hiperurisemia yang tidak ditangani menyebabkan asam urat dalam darah berlebihan sehingga menimbulkan penumpukan kristal asam urat. Apabila kristal berada dalam cairan sendi maka akan menyebabkan penyakit gout. ${ }^{1,3}$

Gout umumnya dialami oleh laki - laki berusia lebih dari 30 tahun. Penyakit gout dapat dikelompokkan menjadi bentuk gout primer dan sekunder. Sebagian besar penyebabnya diperkirakan akibat kelainan proses metabolisme dalam tubuh dan $10 \%$ kasus dialami oleh wanita setelah menopause karena gangguan hormon., Selain dapat menyebabkan gout, hiperurisemia dapat juga menyebabkan kelainan ginjal, tofi sekitar sendi, penyakit jantung, peradangan tulang, stroke dan kencing batu.

Penelitian di Taiwan pada tahun 20052008 menunjukkan peningkatan kejadian hiperurisemia pada lansia wanita sebesar 19,7\% dan prevalensi gout pada lansia wanita sebesar $2,33 \% .^{6}$ Satu survei epidemiologik yang dilakukan di Bandungan, Jawa Tengah atas kerjasama WHOCOPCORD terhadap 4.683 sampel berusia antara 15 - 45 tahun didapatkan bahwa prevalensi gout pada wanita sebesar $11,7 \% .^{7}$ Sedangakan di puskesmas Kecamatan Gajah Mungkur terjadi peningkatan kejadian gout sebesar $17,26 \%$ pada tahun 2011.

Meningkatnya prevalensi gout berhubungan dengan faktor risiko jenis kelamin, asupan tinggi purin, alkohol, obesitas, hipertensi, diabetes melitus, dan dislipidemia. ${ }^{8}$ Selain itu kejadian gout berhubungan dengan gangguan fungsi ginjal dan faktor genetik. ${ }^{9,10}$ Cairan berfungsi sebagai pelarut dan sebagai media pembuangan hasil metabolisme tubuh. Konsumsi cairan tidak beralkohol yang tinggi dapat menurunkan kadar asam urat. ${ }^{4,11}$ Selain itu asupan makanan tinggi purin juga mempengaruhi produksi asam urat karena hasil metabolisme purin yaitu asam urat.

Beberapa penelitian menunjukkan kontroversi hubungan antara asupan purin dan cairan terhadap kadar asam urat. ${ }^{12,13,14,15}$ Gout banyak menyerang pria, namun setelah usia 50 tahun wanita juga berisiko tinggi terkena gout. Menurut catatan kader banyak penduduk di Kecamatan Gajah Mungkur yang sering mengeluh pegal-pegal dan nyeri sendi sehingga dicurigai banyak yang menderita hiperurisemia. Berdasarkan alasan di atas, dilakukan pengaruh asupan purin bersama-sama dengan cairan pengaruhnya terhadap kadar asam urat.

\section{METODE PENELITIAN}

Penelitian dilaksanakan di Kecamatan Gajah Mungkur, Semarang pada bulan Juni - Juli 2012. Penelitian ini termasuk dalam lingkup penelitian gizi masyarakat dan merupakan penelitian observasional dengan desain crosssectional. Populasi target dalam penelitian ini seluruh wanita usia 50-60 tahun di Kecamatan Gajah Mungkur Semarang, sedangkan populasi terjangkau dalam penelitian ini adalah wanita usia 50-60 tahun di Kelurahan Bendan Ngisor, Sampangan, Bendungan dan Gajah Mungkur Semarang. Pengambilan sampel dengan cara consecutive sampling, didapatkan sebanyak 40 orang sebagai subjek. Kriteria subjek pada penelitian ini adalah anggota posyandu lansia wanita yang mempunyai IMT $\leq 30 \mathrm{~kg} / \mathrm{m}^{2}$, berusia 50-60 tahun, sehat, tidak menkonsumsi alkohol dan obat-obatan penurun asam urat serta bersedia menjadi responden dan bersedia melalukan pemeriksaan asam urat. Kriteria eksklusi yang ditetapkan adalah subjek dalam kondisi sakit saat pengukuran atau mengundurkan diri.

Data yang dikumpulkan antara lain karakteristik subjek penelitian, jumlah asupan purin dan cairan serta kadar asam urat. Data karakteristik subjek meliputi nama, usia, pekerjaan dan antropometri meliputi berat badan dan tinggi badan utuk menghitung IMT. Data karakteristik subjek diperoleh menggunakan kuesioner dan data antropometri diukur dengan timbangan digital dan microtoise. Jumlah asupan purin dan cairan diperoleh melalui recall 3x24 jam menggunakan metode wawancara. Data makanan yang diperoleh (ukuran rumah tangga/URT) dikonversikan dalam gram. Data purin dihitung berdasarkan tabel pengelompokan bahan makanan menurut kadar purin. Rata-rata konsumsi per hari makanan sumber purin dibagi seratus kemudian dikalikan dengan kandungan purin sesuai dengan jenis bahan makanan yang ada dalam tabel. Asupan purin normal rentang 500-1000 mg per hari. Di bawah $500 \mathrm{mg}$ per hari dikategorikan rendah dan berlebih bila di atas $1000 \mathrm{mg}$ per hari. ${ }^{16}$ Asupan cairan dari 
makanan diolah menggunakan software nutrisoft, ditambahkan asupan cairan yang diperoleh dari minuman dan kuah. Data asupan cairan yang diperoleh (ukuran rumah tangga/ URT) dikonversikan dalam mililiter. Asupan cairan selama 3 hari dijumlah kemudian dihitung rataratanya. Asupan cairan cukup bila $\geq 1500 \mathrm{ml}$ per hari, kurang bila $<1500 \mathrm{ml}$ per hari. ${ }^{17}$ Kadar asam urat didefinisikan sebagai jumlah asam urat dalam serum yang diukur menggunakan metode enzimatik dibedakan menjadi tinggi bila $>6,00$ $\mathrm{mg} / \mathrm{dl}$, normal bila $2,6-6 \mathrm{mg} / \mathrm{dl}$ dan rendah bila $<2,6 \mathrm{mg} / \mathrm{dl}^{18,19}$ IMT subyek diklasifikasikan berdasarkan IMT orang indonesia dimana IMT $<18,5 \mathrm{~kg} / \mathrm{m}^{2}$ termasuk kurus, $18,5-25 \mathrm{~kg} / \mathrm{m}^{2}$ tergolong normal, $25-27 \mathrm{~kg} / \mathrm{m}^{2}$ tergolong overweight dan $>27 \mathrm{~kg} / \mathrm{m}^{2}$ tergolong obesitas.

Analisis data dilakukan dengan menggunakan program Statistical package for the social science (SPSS) for windows release 16. Analisis univariat digunakan untuk menggambarkan data identitas subjek, IMT, kadar asam urat, jumlah asupan purin dan cairan. Analisis bivariat untuk melihat pengaruh masingmasing asupan purin dan cairan dengan kadar asam urat menggunakan uji statistik regresi linier. ${ }^{20}$

\section{HASIL PENELITIAN \\ Karakteristik subyek}

Subyek dalam penelitian ini berjumlah 40 orang. Usia subyek berkisar antara 50-60 tahun dengan rerata $56,52 \pm 2,74 \mathrm{SD}$. IMT subjek berkisar antara $16,88-29,96 \mathrm{~kg} / \mathrm{m}^{2}$ dengan rerata $26,20 \pm 3,53$ SD. Distribusi frekuensi subyek menurut kategori variabel penelitian dapat dilihat pada tabel 1.

Tabel 1. Distribusi frekuensi kadar asam urat, asupan cairan dan purin

\begin{tabular}{|c|c|c|}
\hline \multirow{2}{*}{\multicolumn{3}{|c|}{ Asupan cairan }} \\
\hline & & \\
\hline$<1500 \mathrm{ml}$ (kurang) & 6 & 15 \\
\hline$\geq 1500 \mathrm{ml}$ (cukup) & 34 & 85 \\
\hline \multicolumn{3}{|l|}{ Asupan purin } \\
\hline$<500$ mg (rendah) & 33 & 82,5 \\
\hline 500-1000mg (normal) & 7 & 17,5 \\
\hline \multicolumn{3}{|l|}{ Kadar asam urat } \\
\hline$<2,6 \mathrm{~g} / \mathrm{dl}$ (rendah) & 1 & 2,5 \\
\hline $2,6-6 \mathrm{~g} / \mathrm{dl}$ (normal) & 37 & 92,5 \\
\hline \multicolumn{3}{|l|}{ (hiperurisemia) } \\
\hline \multicolumn{3}{|l|}{ IMT } \\
\hline$<18,5$ (kurus) & 3 & 7,5 \\
\hline $18,5-25$ (normal) & 9 & 22,5 \\
\hline 25-27 (overweight) & 8 & 20 \\
\hline$>27$ (obesitas) & 20 & 50 \\
\hline
\end{tabular}

Kadar asam urat subyek berkisar antara 2,48-6,45 $\mathrm{mg} / \mathrm{dl}$ dengan rerata 4,36 $\pm 0,99 \mathrm{SD}$ (tabel 1). Tabel 1 menunjukkan bahwa dari 40 subyek, diperoleh 92,5\% $\quad(n=37) \quad$ subjek mempunyai kadar asam urat normal dengan kadar asam urat antara 2,6-6 mg/dl dan 5\% (n=2) mempunyai kadar asam urat tinggi diatas $6 \mathrm{mg} / \mathrm{dl}$. Sisanya sebesar $2,5 \% \quad(n=1)$ mempunyai kadar asam urat di bawah normal.

Sebesar $50 \% \quad(n=20)$ orang subyek termasuk dalam kategori obesitas. Sisanya $22,5 \%$ $(n=9)$ subyek kategori IMT normal, 20\% (n=8) subyek kategori overweight dan 7,5\% subyek termasuk dalam kategori kurus.
Asupan purin berkisar antara 98-697,72 mg per hari dengan rata-rata 324,62 $\pm 367,60 \mathrm{SD}$. Tabel 1 menunjukkan sebagian besar subyek mengkonsumsi purin $<500 \mathrm{mg}$ per hari sebesar $82,5 \% \quad(\mathrm{n}=33) \quad$ dan sisanya $17,5 \% \quad(\mathrm{n}=7)$ mengkonsumsi purin normal 500-1000 mg per hari.

Jumlah asupan cairan berkisar antara $1059,33-2478,33 \mathrm{ml}$ dengan rata- rata $1813,2 \pm$ 148,09 SD. Tabel 1 menunjukkan sebagian besar subyek mengkonsumsi cairan $>1500 \mathrm{ml}$ per hari sebesar $85 \% \quad(n=34)$ dan sisanya $15 \% \quad(n=6)$ mengkonsumsi cairan $<1500 \mathrm{ml}$ per hari. 


\section{Hubungan antar variabel}

Berdasarkan uji normalitas, didapatkan data asupan purin, cairan dan kadar asam urat berdistribusi normal. Hasil uji bivariat menggunakan regresi linier sederhana menunjukkan bahwa asupan purin berpengaruh terhadap kadar asam urat $(p=0,000)$, sedangkan jumlah asupan cairan tidak berpengaruh terhadap kadar asam urat $(p=0,884)$.

Hasil uji regresi linier di atas didapatkan konstanta 3,122 dan a sebesar 0,004. Didapatkan persamaan $\mathrm{y}=3,122+0,004$ (purin), ini menunjukkan besarnya pengaruh asupan purin terhadap kadar asam urat. Jadi semakin tinggi konsumsi purin semakin tinggi pula kadar asam urat. Nilai Adjusted $\mathrm{R}$ Square adalah sebesar $30,3 \%$, artinya persamaan yang diperoleh mampu menjelaskan kadar asam urat sebesar $30,3 \%$. Sisanya $69,7 \%$ dijelaskan oleh variabel lain yang tidak diteliti.

Berikut grafik regresi linier asupan purin purin terhadap kadar asam urat :

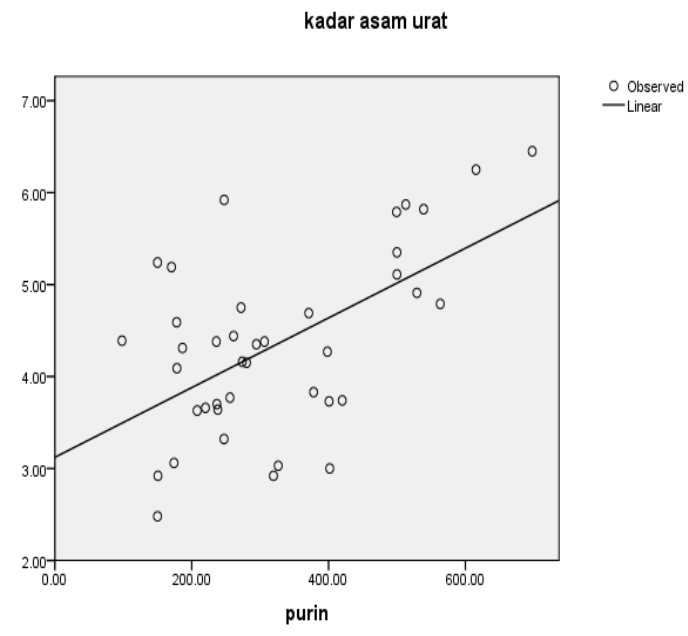

Gambar 1. Grafik regresi linier asupan purin purin terhadap kadar asam urat

\section{PEMBAHASAN}

Subyek dalam penelitian ini merupakan wanita pralansia dengan rentang usia 50-60 tahun. Penelitian ini memilih subyek wanita usia tersebut karena wanita pada usia tersebut juga mempunyai risiko terkena penyakit gout.

Presentase kejadian gout pada wanita lebih rendah daripada pada pria. Walaupun demikian, kadar asam urat pada wanita meningkat pada saat menopause. Penelitian menunjukkan sebagian besar kadar asam urat subyek $(92,5 \%)$ berada dalam rentang normal, yaitu antara 2,6-6 mg/dl, dan hanya 2 orang subyek (5\%) yang mengalami hiperurisemia. Kadar asam urat dipengaruhi oleh banyak faktor, salah satunya asupan purin dan cairan. Pola makan berpengaruh terhadap peningkatan kadar asam urat. ${ }^{16,21}$ Subyek yang memiliki kadar asam urat normal sebagian besar sudah menjaga pola makan. Asupan purin keseluruhan subyek tidak ada yang lebih dari batasan asupan purin normal yaitu $1000 \mathrm{mg}$ per hari. Mengkonsumsi makanan tinggi purin dapat meningkatkan kadar asam urat dalam darah. Selain itu, asupan cairan sebagian besar subyek (85\%) mengkonsumsi $>1500$ cairan setiap harinya. Dua orang subyek yang mengalami hiperurisemia, mengkonsumsi purin $>500 \mathrm{mg}$ per hari, asupan cairan semuanya $>1500 \mathrm{ml}$ per hari, sedangkan IMT normal dan overweight.

Penelitian ini ditemukan jumlah asupan purin berpengaruh terhadap kadar asam urat. Hal ini sesuai dengan teori, dimana mengkonsumsi makanan tinggi purin dapat meningkatkan kadar asam urat. Asupan purin pada subjek sebagian besar kurang dari $500 \mathrm{mg}$ per hari. Asupan purin normal per hari adalah 500-1000 mg. Makanan yang mengandung zat purin akan diubah menjadi asam urat. ${ }^{21}$ Purin adalah salah satu senyawa basa organik yang menyusun asam nukleat atau inti dari sel dan termasuk dalam kelompok asam amino, unsur pembentuk protein. Asam nukleat yang dilepas di traktus intestinalis akan diurai menjadi mononukleotida oleh enzim ribonuklease, deoksiribonukliease dan polinukleotidase. Kemudian enzim nukleotidase dan fosfatase menghidrolisis mononukleotida menjadi nukleotida yang kemudian bisa diserap atau diurai lebih lanjuat oleh enzim fosforilase intestinal menjadi basa purin serta pirimidin. Proses pembentukan asam urat sebagian besar dari metabolisme nukleotida purin endogen, guanosine monophosphate (GMP), inosine monophosphate (IMP), dan adenosine monophosphate (AMP). Enzim xanthine oxidase mengkatalis hypoxantin dan guanine dengan produk akhir asam urat. Manusia tidak mempunyai enzim urikase,sehingga produk akhir dari katabolisme purin adalah berupa asam urat. ${ }^{21}$

Makanan tinggi purin salah satunya banyak terkandung dalam makanan laut, jeroan, dan kacang-kacangan. ${ }^{16}$ Dua orang subyek yang mengalami hiperurisemia makanan yang dikonsumsi adalah makanan jenis tinggi purin cukup sering seperti ayam sarden, dan ikan. Sedangkan untuk kelompok subjek asam urat normal makanan dengan kandungan purin lebih rendah dalam bentuk protein nabati seperti tahu, 
tempe dan sayur kacang dengan jumlah $<500 \mathrm{mg}$ per hari.. Purin dalam bahan makanan berbedabeda kandungan dan bioavailabilitasnya, selain itu perubahan purin menjadi asam urat juga tergantung pada selularitas relatif dan aktifitas transkripsi serta metabolik selular makanan tersebut. ${ }^{22}$ Menurut Krisnatuti, bahan pangan yang tinggi kandungan purinnya dapat meningkatkan kadar urat dalam darah antara $0,5-0,75 \mathrm{~g} / \mathrm{ml}$ purin yang dikonsumsi. ${ }^{23}$

Pengaruh asupan cairan terhadap kadar asam urat secara statistik tidak bermakna $(p>0,05)$. Hal ini bertentangan teori. Manusia memenuhi kebutuhan air dari luar tubuh melalui minuman dan makanan. Minuman memiliki kontribusi tertinggi dalam pemenuhan kebutuhan air pada tubuh manusia. Cairan merupakan salah satu media pembuangan hasil metabolit tubuh. Jika seseorang menkonsumsi cairan dalam jumlah tinggi, reabsorpsi air di ginjal menurun dan ekskresi zat terlarut air meningkat. Asupan minimal cairan pralansia yaitu sebesar $1500 \mathrm{ml}$ per hari. ${ }^{17}$ Namun kebutuhan seseorang akan air berbeda-beda tergantung tingkat aktifitas fisik, suhu dan lingkungan. ${ }^{24}$ Selain itu cairan juga dipengaruhi oleh usia, berat badan, asupan energi dan luas permukaan tubuh. Rata-rata asupan cairan subyek berada dalam kategori cukup yaitu sebagian besar sudah mengkonsumsi cairan lebih dari $1500 \mathrm{ml}$ per hari. Pada penelitian ini secara statistik tidak menunjukkan adanya hubungan antara asupan cairan dengan kadar asam urat. Walaupun secara uji statistik cairan terhadap asam urat tidak bermakna, ditemukan 2 orang subyek dengan konsumsi purin dalam jumlah yang sama, IMT hampir sama sedangkan asupan cairan mereka berbeda, hasilnya yang mengkonsumsi cairan lebih dari $2000 \mathrm{ml}$ kadar asam uratnya rendah. Subyek lainnya yang mengkonsumsi cairan rendah dibawah $1500 \mathrm{ml}$ mempunyai kadar asam urat tinggi. Kadar asam urat dipengaruhi oleh beberapa faktor, salah satunya yang berpengaruh adalah pola makan, terutama konsumsi makanan tinggi zat purin. Konsumsi purin subyek terbilang rendah dan juga konsumsi cairan cukup menyebabkan kadar asam urat subyek sebagian besar normal.

\section{KETERBATASAN PENELITIAN}

Tingkat aktivitas fisik dan menopause subjek dalam penelitian ini tidak diukur. Selain itu desain penelitian menggunakan desain cross sectional, dimana desain ini lemah untuk menilai hubungan sebab akibat.

\section{SIMPULAN}

Hasil penelitian menunjukkan mayoritas subyek memiliki kadar asam urat normal, yaitu 92,5\% dan hanya 2 orang subjek (5\%) yang ditemukan hiperurisemia. Asupan purin sebagian besar subjek tergolong rendah, sedangkan asupan cairan $85 \%$ subyek tergolong normal. Asupan cairan tidak berpengaruh terhadap kadar asam urat, sebaliknya asupan purin berpengaruh terhadap peningkatan kadar asam urat.

\section{SARAN}

Bagi penderita hiperurisemia di Kecamatan Gajah Mungkur diharapkan mengurangi asupan purin, karena terbukti dapat meningkatkan kadar asam urat. Perlu dilakukan penelitian lebih lanjut mengenai faktor lain yaitu usia menopause dan tingkat aktivitas fisik. Selain itu perlu dilakukan penellitian dengan desain penelitian yang lebih baik.

\section{DAFTAR PUSTAKA}

1. Badan Pusat Statistik. Pedoman pencacahan susenas kor juli 2009. Jakarta. Badan pusat statistik ; 2009.

2. Carter, Michael A. Buku Ajar Patofisiologi edisi 6. Jakarta: EGC ; 2006.p.206-237.

3. Tjokorda Raka Putra. Buku Ajar Ilmu Penyakit Dalam jilid II edisi IV. Jakarta : EGC ; 2007. hal. 1203 .

4. Kaparang K. Penyakit Kaum Bangsawan, Jakarta : PT Etika Media Utama ; 2007.p.18 39.

5. Sylvia Saraswati. Diet sehat untuk penyakit asam urat,diabetes, hipertensi dan stroke. Jakarta : A plus Books ; 2009.p. 19-23.

6. Chuang SY, Lee SC, Hsien YT. Trends in hyperuricemia and gout prevalence : Nutrition and health Survey in Taiwan from 1993-1996 to 2005-2008. Asia Pac Clin Nutr.2011;20(2) :301-8.

7. Darmawan J, Rasker JJ, Nuralim H, The effect of Control and Self - Medication of Chronic Gout in a Developing Country, http//medisdankomputer.co.cc, Outcome after 15 Years, 2009.

8. Luk AJ and Simkin PA, Epidemiologi of Hyperuricemia and Gout, The American Journal of Managed Care, Vol 11, 2005 : 11 : $435-442$.

9. Wibowo, Kaparang AM, Moeis ES, Kapojos AL. Renal function in Minahasanese patients with chronic gout arthritis antophi. Acta Med Indones.2005 Apr-Jun; 37(2) : 61-65.

10. Chen S, Du H, Wang Y, Xxu L. The epidemiology study of hyperurisemia and gout in a community population of Huangpu District 
in Shanghai. Chin Med J. 1998 Mar; iii(3) : 228-30.

11. Guyton, Hall. Buku Ajar Patofisiologi kedokteran edisi 11. Jakarta : EGC; 2006: 1242-1246.

12. Early Fajarina. Analisis Pola Konsumsi dan Pola Aktivitas Kadar Asam Urat Pada Lansia Wanita Peserta Pemberdayaan Lansia di Bogor.Skripsi.Bandung:FEM IPB;2011.

13. Nova Satya. Hubungan asupan karbohidrat, protein, lemak, air, indeks massa tubuh dengan kadar asam urat pada laki-laki denganberat badan berlebih . Skripsi.Semarang:FK UNDIP ;2010.

14. Rini Setyoningsihi. Faktor-faktor yang berhubungan dengan kejadian hiperurusemia pada pasien rawat jalan di RSUP dr Kariadi Semarang. Skripsi. Semarang: FK UNDIP ; 2009.

15. Andry Saryono, Arif Setyo Upoyo. Analisis faktor-faktor yang mempengaruhi kadar asam urat pada pekerja kantor di desa karang turi, kecamatan bumiayu kabupaten brebes. The soedirman of Nursing.2009 Maret. volume 4.

16. Choi HK, Karen Atkinson, Elizabeth WK, Walter W, Gary C.Purine Rich Foods, Dairy and Protein Intake, and the Risk of Gout in Men. N Engl J Med 2004 ;350:1093-103.

17. Chernoff, Roni. Geriatric Nutrition the health professional's Handbook. Boston: Jones and Bartlett publishers ; 2006.p.26-28.

18. Rosa Lelyana. Pengaruh kopi terhadap kadar asam urat darah. Tesis . Semarang: FK UNDIP ; 2008.

19. Herlianty MP. Faktor gizi sebagai determinan hiperurisemia. Konas XII Persagi. Persatuan Ahli Gizi Indonesia; 2002.p.289-305

20. M. Sopiyudin Dahlan. Statistik untuk Kedokteran dan Kesehatan. Jakarta :Salemba medika ; 2008.p.31-57,209-214.

21. Murray RK, Granner DK, Mayes PA, Rowell VW. Biokimia harper. Edisi 27th edition. Singapore: McGraw Hill; 2006.p. 184,301-309.

22. Choi HK, Mount DB, Reginato AM. Patogenesis of Gout. Annals of Internal Medicine; Oct 4, 2005;143,7:499-516. Available at: http://www.internalmedicine.com.By on August 16;2008.

23. Krisnatuti, Diah, dkk,. Perencanaan Menu Untuk Penderita Asam Urat. Jakarta: Panebar Swadaya ; 2008.

24. Raharja EM. Peran nutrisi pada hiperurisemia. Ebers papyrus vol 8 no 1. Jakarta: 2002:47-50. 